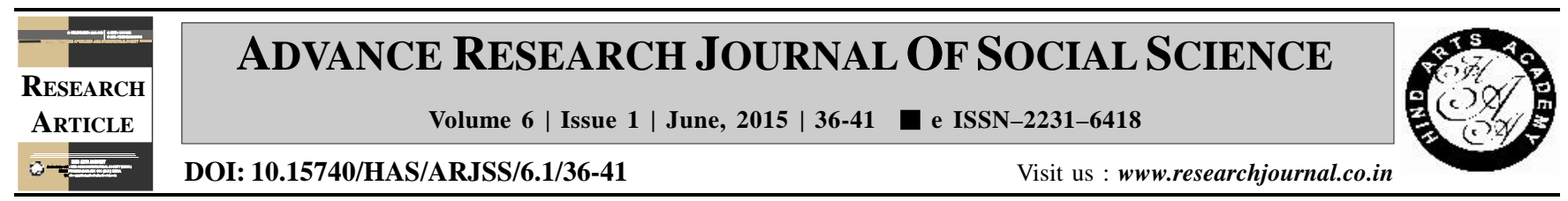

\title{
Aspirations of rural youth towards self-development
}

\author{
V.S. Tekale*, M.D. Mali ${ }^{1}$ and J.I. Shaikh ${ }^{2}$
}

Department of Extension Education, College of Agriculture, NAGPUR (M.S.) INDIA

(Email: vishnukantt@ rediffmail.com)

${ }^{1}$ College of Agriculture, NAGPUR (M.S.) INDIA

${ }^{2}$ Department of Extension Education, Mahatma Phule Krishi Vidyapeeth, Rahuri, AHMEDNAGAR (M.S.) INDIA

\section{ARTICLE INFO :}

$\begin{array}{lll}\text { Received } & : & 13.03 .2015 \\ \text { Revised } & : & 15.04 .2015 \\ \text { Accepted } & : & 27.04 .2015\end{array}$

KEY WORDS :

Aspiration, Self development

\section{HOW TO CITE THIS ARTICLE :}

Tekale, V.S., Mali, M.D. and Shaikh, J.I. (2015). Aspirations of rural youth towards self-development. Adv. Res. J. Soc. Sci., 6 (1) : 36-41.

*Author for correspondence

\begin{abstract}
The present research "Aspirations of rural youth towards self-development" was conducted in Ramtek and Kamthi taluka of Nagpur district of Maharashtra State. 100 youth were selected randomly from 10 villages. The data was collected by personal interview of the rural youth with the help of interview schedule. In case of profile of rural youth nearly half of respondents $(46.00 \%$ ) had medium age (24 to 28 years). The 30.00 per cent of rural youth educated up to college level. Majority of respondents ( $71.00 \%$ ) had medium experience in farming (4 to 7 years) and 72.00 per cent had medium family size (4 to 7 members), majority of respondents $(56.00 \%$ ) had semimedium (2.01 to 4.00 ha) land holding, 40.00 per cent respondents had high social participation and 46.00 per cent had medium extension contact, whereas 44.00 per cent respondents had high mass media exposure and majority of respondents $(59.00 \%)$ had medium cosmopoliteness. It was observed that majority of respondents $(51.00 \%)$ performed medium level overall role in village development activities. In case of role of rural youth in agricultural development activities majority of respondents $(56.00 \%)$ were played role in sowing, drilling, dibbling, etc. activities, in case of rural youth role in social development activities of village majority of respondents $(52.00 \%)$ played role in cultural and recreational programmes. In case of role of rural youth in economic development activities over two fifth of respondents $(43.00 \%)$ were participated in work of marketing of agriculture product.
\end{abstract}

